\title{
ChemComm
}

\section{A triple-channel lab-on-a-molecule for triple-anion quantification using an iridium(III)-imidazolium conjugate $\dagger$}

50,5756

Kun Chen and Michael Schmittel*

Received 24th February 2014

Accepted 7th April 2014

DOI: $10.1039 / c 4 c c 01421 a$

www.rsc.org/chemcomm

\begin{abstract}
A lab-on-a-molecule, based on the iridium(III)-imidazolium conjugate 1 , allows competitive quantification of three distinct anions in a mixture using three interrogation channels: $\mathrm{F}^{-}$is detected and quantified via UV-Vis, $\mathrm{H}_{2} \mathrm{PO}_{4}{ }^{-}$using photoluminescence and $\mathrm{AcO}^{-}$ using electrochemiluminescence.
\end{abstract}

The development of anion chemosensors is a burgeoning area of chemistry not only because of legal requirements for quantitative sensing in medicine and the environment but also due to vibrant academic challenges, such as molecular logic and dynamic receptors. ${ }^{1}$ Compared with cations, anions possess a lower charge-to-radius ratio, varying geometries and a distinctive $\mathrm{pH}$ dependence, so that anion detection is also affected by solvent properties. ${ }^{1 a}$ As a result, the design of selective anion receptors is much more demanding than that of cations, not to speak of multi-anion receptors. Among the concepts for multianalyte detection that are based on a single probe, such as lab-ona-molecule, ${ }^{2}$ keypad lock, ${ }^{3}$ relay assay ${ }^{4}$ and displacement assay, ${ }^{1 b}$ the lab-on-a-molecule is known for its competitive assay. While the original conception of a lab-on-a-molecule was conceived with regard to molecular logic, ${ }^{2}$ we later extended the concept to multiplex detection in different channels. ${ }^{5}$ As such, it is an alternative strategy ${ }^{6}$ to arraybased, ${ }^{7}$ highly integrated ${ }^{8}$ and combinatorial approaches. ${ }^{9}$ Without the need to integrate several binding/reaction sites, multi-channel lab-on-amolecule probes ideally do not require complex synthesis but a specific binding mechanism and a unique signal response for each analyte within its detection channel. Although ample efforts have been devoted to and several examples have been addressed to, ${ }^{10}$ a lab-on-a-molecule for more than two anions has remained elusive so far.

Based on their unique photophysical properties, long excited-state lifetimes and stable redox states, ruthenium and cyclometalated iridium complexes display an armada of phenomena that are profitable for sensing, such as ligand-centred transitions (LC), interligand

Center for Micro- and Nanochemistry and Engineering, Organische Chemie, Universität Siegen, Adolf-Reichwein-Strasse, D-57068, Siegen, Germany. E-mail:schmittel@chemie.uni-siegen.de

$\dagger$ Electronic supplementary information (ESI) available: Synthesis, Job plots, UV-vis, competitive assays, DPV. See DOI: 10.1039/c4cc01421a energy transfer (ILET) and/or metal-ligand charge transfer (MLCT). ${ }^{11}$ By using ligands with energy levels that are easily modulated by additives, ${ }^{12}$ we expected to trigger distinct photophysical changes for each analyte. Moreover, redox changes at the metal-ligand system should open further options to tune interactions with analytes, possibly causing unique electrochemiluminescence (ECL) responses. ${ }^{10 e, h, i}$ All these features and our recent results ${ }^{5,13}$ illustrate that ruthenium and iridium complexes are indeed great candidates for the lab-on-a-molecule approach.

Over the years, the imidazolium unit has been developed as an excellent receptor for anion binding, ${ }^{14}$ mostly based on electrostatic interactions and hydrogen bonding. However, the non-specificity of these interactions is a problem for selective sensing. ${ }^{1 b}$ We thus envisaged to implement anion-imidazolium selectivity by introducing specific auxiliary interactions and precise spatial arrangements. ${ }^{14}$ Our endeavours have led to the iridium-based lab-on-a-molecule 1 (Scheme 1), a molecular chemosensor for $\mathrm{F}^{-}, \mathrm{H}_{2} \mathrm{PO}_{4}{ }^{-}$and $\mathrm{AcO}^{-}$, whose energy levels are modulated depending on the interrogation channel and the anion-imidazolium interaction. The sensing of probe 1 was tested in three channels using the following array of anions: $\mathrm{H}_{2} \mathrm{PO}_{4}{ }^{-}, \mathrm{HSO}_{4}{ }^{-}, \mathrm{F}^{-}, \mathrm{Cl}^{-}, \mathrm{Br}^{-}, \mathrm{PhCOO}^{-}, \mathrm{BF}_{4}{ }^{-}, \mathrm{PF}_{6}{ }^{-}, \mathrm{ClO}_{4}{ }^{-}$, $\mathrm{NO}_{3}{ }^{-}, \mathrm{CF}_{3} \mathrm{SO}_{3}{ }^{-}, \mathrm{MeSO}_{3}{ }^{-}, \mathrm{AcO}^{-}$and $\mathrm{TsO}^{-}$(Fig. 1). Moreover, complex 2 was prepared for comparison to cross-examine the detection mechanism.

In the range of $350-500 \mathrm{~nm}$, the UV-Vis absorption spectra of complexes 1 and 2 are very similar (Fig. S1, ESI $\dagger$ ), while their response to anions is totally different. Upon addition of $\mathrm{F}^{-}$to a solution of $\mathbf{1}$ in acetonitrile (MeCN), a broad absorption and a hyperchromic effect at $457 \mathrm{~nm}$ were observed (Fig. 2). A less hyperchromic effect was seen

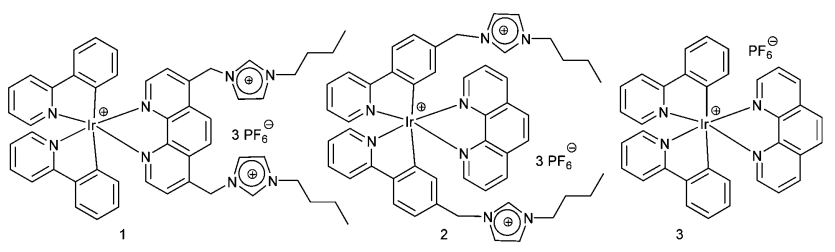

Scheme 1 Structures of complexes 1-3. 


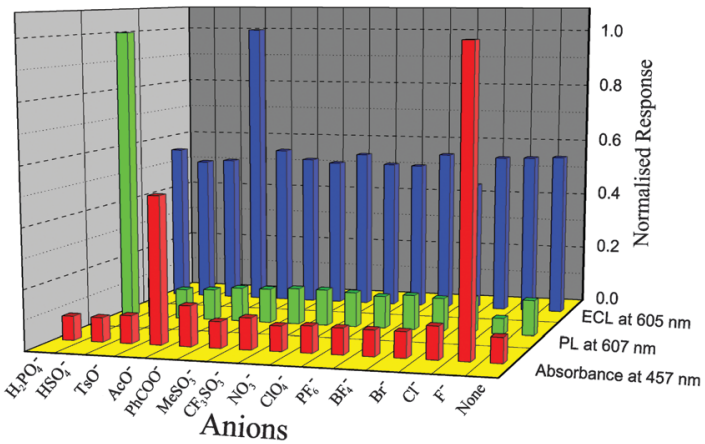

Fig. 1 Relative response of complex 1 in UV-Vis, PL (both upon addition of 5 equiv. of anions), and ECL (addition of 200 equiv. of anions).

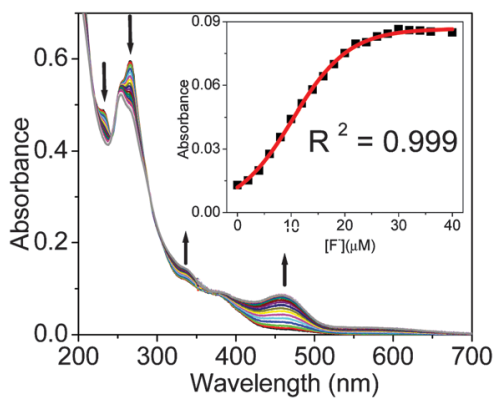

Fig. $2 U V$-Vis absorption spectra of probe $1(10 \mu \mathrm{M})$ in the presence of $\mathrm{F}^{-}$ $\left(0\right.$ to $25 \mu \mathrm{M}$ ) in MeCN. Inset: titration of 1 with $\mathrm{F}^{-}$is monitored at $457 \mathrm{~nm}$.

upon addition of $\mathrm{AcO}^{-}$. Other anions did not induce any response in this range. In the case of probe 2 , none of the anions caused any change at all.

The appearance of a new CT band at $457 \mathrm{~nm}$ for 1 in the presence of $\mathrm{F}^{-}$suggests that a new electron-donating unit is formed. Diagnostically, the ${ }^{1} \mathrm{H}$ NMR of 1 in the presence of $\mathrm{F}^{-}$(2.8 equiv.) exhibits a downfield shift $(\Delta \delta=0.62 \mathrm{ppm})$ for the imidazolium proton $2-\mathrm{H}$ suggesting an ionic hydrogen-fluoride bond (Fig. S2, ESI $\dagger$ ). In the presence of $\mathrm{F}^{-}$(2.8 equiv.), H/D exchange was observed in a mixture of $\mathrm{CD}_{3} \mathrm{CN} / \mathrm{CD}_{3} \mathrm{OD}(\mathrm{v} / \mathrm{v}, 9: 1)$ at both $2-\mathrm{H}$ and the methylene protons of complex 1. Conversely, only 2-H exchanged in complex 2 (Fig. S3 and $\mathrm{S} 4, \mathrm{ESI} \dagger$ ). Apparently, deprotonation of the methylene protons by $\mathrm{F}^{-} / \mathrm{AcO}^{-}$is the reason for an increased conjugation length in $\mathbf{1}$ (Scheme 2a).

The Job plot unveils a 1:2 stoichiometry for adduct $\mathbf{1} \cdot\left(\mathrm{F}^{-}\right)_{2}$ (Fig. S5, ESI $\dagger$ ) and the UV-Vis titration indicates $\log \beta=9.71 \pm 0.30$

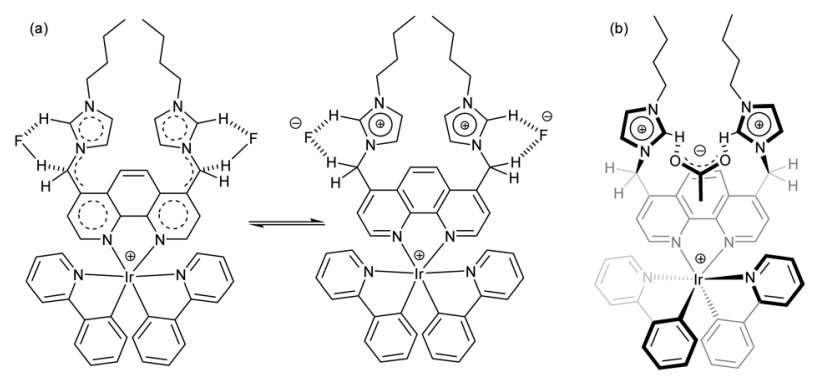

Scheme 2 Relevant interaction in the (a) UV-Vis and (b) ECL detection.
Table 1 Spectroscopic and electrochemical data of complexes 1-3

\begin{tabular}{|c|c|c|c|c|c|}
\hline \multirow[b]{2}{*}{ Probe } & \multicolumn{2}{|c|}{$\underline{\text { Redox potentials }}^{a}$} & \multirow{2}{*}{$\begin{array}{l}\Delta E / \mathrm{eV} \\
\left(E_{\mathrm{ox}}-E_{\mathrm{red}}\right)\end{array}$} & \multirow[b]{2}{*}{$\mathrm{PL} \lambda_{\mathrm{em}} / \mathrm{nm}$} & \multirow[b]{2}{*}{ ECL $\lambda_{\mathrm{em}} / \mathrm{nm}$} \\
\hline & $E_{\text {ox }} / \mathrm{V}$ & $E_{\text {red }} / \mathrm{V}$ & & & \\
\hline 1 & 1.41 & $\begin{array}{l}-0.99 \text { (im) } \\
-1.24 \text { (phen) } \\
-1.39 \text { (im) }\end{array}$ & 2.40 & 660 & 605 \\
\hline 2 & 1.53 & $\begin{array}{l}-1.20 \text { (phen) } \\
-1.69 \text { (im) } \\
-1.89 \text { (im) }\end{array}$ & 2.73 & 564 & 563 \\
\hline 3 & 1.38 & -1.25 & 2.63 & 597 & $590^{b}$ \\
\hline
\end{tabular}

${ }^{a}$ The potential referenced to $\mathrm{Fc}^{*}{ }^{b}$ ECL of complex 3 see ref. 15.

as the association constant. A relationship (linear: 2-20 $\mu \mathrm{M}$ ) allows quantification of $\mathrm{F}^{-}$at an LOD of $0.21 \mu \mathrm{M}$ (limit of detection). In competition assays, the detection is only disturbed by the amphoteric acid-base pairs $\mathrm{H}_{2} \mathrm{PO}_{4}{ }^{-}$and $\mathrm{HSO}_{4}{ }^{-}$that will interact with any deprotonation scheme. Other anions do not interfere even in a competitive assay (Fig. S6, ESI $\dagger$ ).

In the parent iridium complex 3, with the HOMO residing on the phenylpyridine and the LUMO on the phenanthroline ligand, the emission is centred at $597 \mathrm{~nm} .{ }^{16}$ In contrast, 1 emits at $660 \mathrm{~nm}$. With an oxidation potential at $1.41 \mathrm{~V}$ and three close reduction potentials at $-0.99,-1.24$ and $-1.39 \mathrm{~V}$ vs. $\mathrm{Fc}^{*} \ddagger$ (Fig. S7, ESI $\dagger$ ), the band gap $\Delta E=E_{\mathrm{ox}}-E_{\mathrm{red}}=2.40 \mathrm{~V}$ of 1 is smaller than that $(2.63 \mathrm{~V})$ of complex 3 (Table 1). The lower energy emission of 1 indicates that its photoluminescence (PL) originates from low-lying triplet states of the auxiliary ligand ( $\left.{ }^{3} \mathrm{LX}\right)$ and ILET. ${ }^{17}$ In contrast, complex 2 exhibits a high-energy emission at $566 \mathrm{~nm}$ because the imidazolium unit, though not conjugated with the phenylpyridine ligand, lowers the HOMO energy while the LUMO energy is as in 3. Consequently, the band gap $\Delta E=2.73 \mathrm{~V}$ of 2 is larger than that $(2.63 \mathrm{~V}$ ) of complex 3 .

In the PL channel, both 1 and 2 exhibit a diagnostic light-up response toward $\mathrm{H}_{2} \mathrm{PO}_{4}{ }^{-}$. Upon addition of 5 equiv. of $\mathrm{H}_{2} \mathrm{PO}_{4}{ }^{-}$to 1 , the emission increases 7 -fold along with a blue shift from 660 to $607 \mathrm{~nm}$ (Fig. 3). In contrast, complex 2 displays an $8 \mathrm{~nm}$ red shift and an 8-fold PL enhancement at $564 \mathrm{~nm}$ (Fig. S8 and S9, ESI $\dagger$ ). Job plots indicate that each imidazolium interacts with one equiv. of $\mathrm{H}_{2} \mathrm{PO}_{4}{ }^{-}$ in both 1 (Fig. S10, ESI $\dagger$ ) and 2 (Fig. S11, ESI $\dagger$ ). UV-Vis (Fig. S12 and $\mathrm{S} 13, \mathrm{ESI} \dagger)$ and PL titrations display comparable binding constants for both probes $(\log \beta=7.18 \pm 0.10$ for $1 ; \log \beta=7.89 \pm 0.10$ for 2$)$.

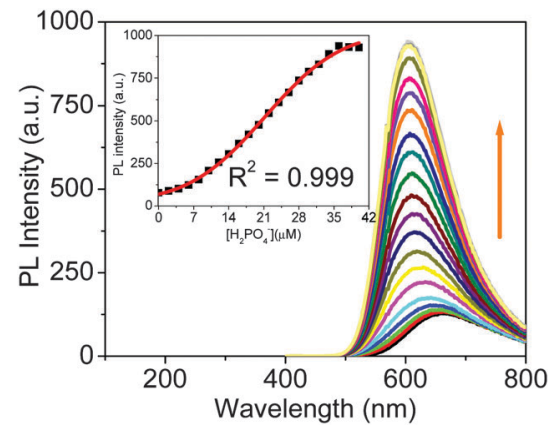

Fig. $3 \mathrm{PL}$ spectra $\left(\lambda_{\text {ex }}=272 \mathrm{~nm}\right)$ of $1(10 \mu \mathrm{M})$ in the presence of $\mathrm{H}_{2} \mathrm{PO}_{4}$ ( 0 to $42 \mu \mathrm{M}$ ) in MeCN. Inset: PL titration $\left(\lambda_{\mathrm{em}}=607 \mathrm{~nm}\right.$ ) of 1 with $\mathrm{H}_{2} \mathrm{PO}_{4}{ }^{-}$. 


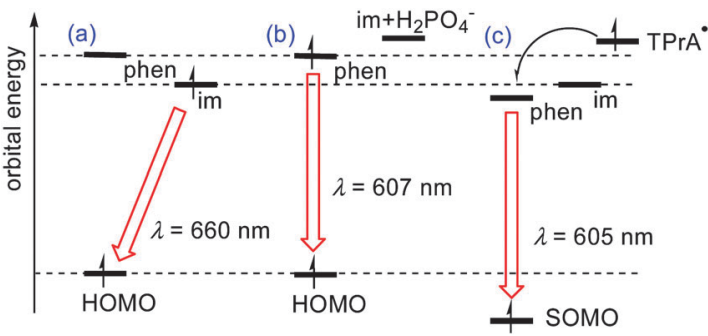

Scheme 3 Energy diagram for the $\mathrm{PL}$ (a) of $\mathbf{1}^{3+}$, (b) of $\mathbf{1}^{3+}+\mathrm{H}_{2} \mathrm{PO}_{4}{ }^{-}$, and (c) for the ECL of $\mathbf{1}^{3+}$

A good relationship (linear: 6-34 $\mu \mathrm{M}$ ) and LODs for 1 (68 nM) and 2 (65 $\mathrm{nM}$ ) were obtained. In a competitive assay, only $\mathrm{F}^{-}$disturbs the detection by reducing the PL of $1 \& \mathrm{H}_{2} \mathrm{PO}_{4}^{-}$at $607 \mathrm{~nm}$ by $64 \%$ (Fig. S15, ESI $\dagger$ ) and that of $2 \& \mathrm{H}_{2} \mathrm{PO}_{4}{ }^{-}$at $564 \mathrm{~nm}$ by $30 \%$ (Fig. S16, $\mathrm{ESI} \dagger)$, but this interference is fully eliminated using $\mathrm{Me}_{3} \mathrm{SiCl}$ as a trapping agent for $\mathrm{F}^{-}$(Fig. S17 and S18, ESI $\dagger$ ). The presence of $\mathrm{H}_{2} \mathrm{PO}_{4}{ }^{-}$leads to a slight ${ }^{1} \mathrm{H}$ NMR downfield shift at the imidazolium proton $2-\mathrm{H}$ in $\mathbf{1}$ (Fig. S19, ESI $\dagger$ ) and 2 (Fig. S20, ESI $\dagger$ ), exclusively. The PL data were not disturbed by up to $5 \%(\mathrm{v} / \mathrm{v})$ water in $\mathrm{MeCN}$.

The PL of iridium complexes is governed by the energy level of the lowest-lying ligand (triplet) ${ }^{11 c}$ and the energy gap law. ${ }^{12}$ Emission of $\mathbf{1}$ is weak due to the small energy gap between ${ }^{3} \mathrm{LX}$ (imidazolium $=$ im) and the ground state. Association with $\mathrm{H}_{2} \mathrm{PO}_{4}{ }^{-}$raises the LUMO level of ${ }^{3} \mathrm{LX}(\mathrm{im})$ above that of the phenanthroline. As a result, the higher-energy ${ }^{3} \mathrm{M}_{\text {IrPpy }} \mathrm{L}_{\text {phen }} \mathrm{CT}$ emission becomes favoured (Scheme 3). In contrast, the imidazoliums in 2 are attached to the phenylpyridines, the latter representing the HOMO. Upon addition of $\mathrm{H}_{2} \mathrm{PO}_{4}{ }^{-}$, all potentials of 2 shift cathodically except that of the phenanthroline ligand (Fig. S22, ESI $\dagger$ ). Due to increasing orbital energies and a constant LUMO level, the energy difference between ${ }^{1}$ MLCT and ${ }^{3}$ LC states is reduced, which is well known to increase the quantum yield. ${ }^{12}$

In oxidative ECL scans using tri- $n$-propylamine (TPrA) as a co-reactant (for mechanism, see ESI $\dagger$ ), complex 1 displays an emission at $605 \mathrm{~nm}$ in MeCN-Tris buffered aqueous solution (9/1, v/v $\mathrm{MeCN} / 10 \mathrm{mM}$ Tris-ClO ${ }_{4}$ buffer, $\left.\mathrm{pH}=7.2\right)$. The notable difference $\Delta \lambda_{\mathrm{em}}=55 \mathrm{~nm}$ between ECL and PL $\left(\lambda_{\mathrm{em}}=660 \mathrm{~nm}\right)$ is readily explained by different HOMO/LUMO states in PL and ECL. The PL originates from an imidazolium-based LUMO $\left(E_{\mathrm{pc}}=-0.99 \mathrm{~V}\right)$, and thus is not typical for $\left[\operatorname{Ir}(\text { ppy })_{2}(\text { phen })\right]^{+}$systems, while under ECL conditions, both the $\mathrm{Ir}^{4+}$-based SOMO and the phenanthroline-based LUMO are lowered in energy. As the latter falls below the energy level of the imidazolium unit (Scheme 3c), the ECL arises from a characteristic $\mathrm{M}_{\text {IrPpy }} \mathrm{L}_{\text {phen }} \mathrm{CT}$ that is typically located at $550-600 \mathrm{~nm}$. In contrast, complex 2 displays an ECL emission centred at $563 \mathrm{~nm}$, which is congruent with that observed in PL. In both excitation modes, the LUMO of 2 resides on the phenanthroline (Fig. S22, ESI $\dagger$ ).

The difference in the ECL signature of both probes should have a bearing on anion detection. Indeed, probe 1 shows a highly selective ECL enhancement in the presence of $\mathrm{AcO}^{-}$(Fig. 4) with the response not being disturbed by any other anion from our set (Fig. S23, ESI $\dagger$ ). A relationship (linear: $0.0-0.6 \mathrm{mM}$ ) allows quantification with an LOD = $0.17 \mathrm{mM}$. In contrast, complex 2 does not respond to $\mathrm{AcO}^{-}$at all in the ECL channel.

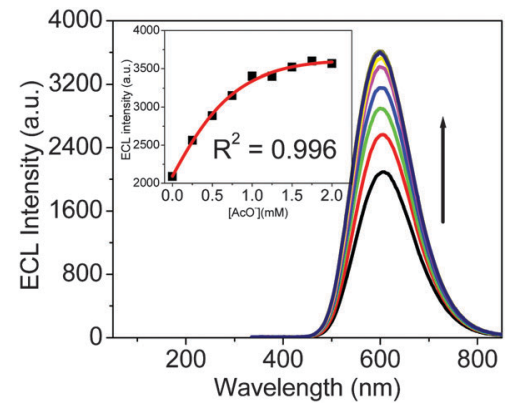

Fig. $4 \mathrm{ECL}$ spectra of complex $1(10 \mu \mathrm{M})$ in the presence of $\mathrm{AcO}^{-}(0$ to $2 \mathrm{mM}$ ) in MeCN-Tris buffer aqueous solution (9/1, v/v, $10 \mathrm{mM}, \mathrm{pH}=7.2$ ). Inset: titration ( $\mathrm{ECL}$ at $605 \mathrm{~nm}$ ) curve of 1 in the presence of $\mathrm{AcO}^{-}$.

The selective ECL response of complex 1 to $\mathrm{AcO}^{-}$remains somewhat speculative. In a mechanistic test, propionate equally triggered ECL enhancement, while benzoic acid did not have any effect. We suggest that the positively charged imidazolium units and the iridium centre of $\mathrm{1}^{+}$form a tricationic cavity that serves to bind a single $\mathrm{AcO}^{-}$ in a bifurcated hydrogen bond, a coordination mode that is well documented in spatially apt bisimidazolium salts. ${ }^{18}$ As the cavity (Scheme 2b) demands a small-sized anion, propionate still works, but benzoate fails. The binding of the acetate anion next to the phenanthroline raises the LUMO level (phenanthroline) of 1 slightly, shifting the emission moderately to higher energy (by $7 \mathrm{~nm}$ ). Moreover, the ECL intensity is enhanced because the acetate serves to precoordinate $\operatorname{TPrA}^{+} \bullet$, which is the source of $\operatorname{TPrA}^{\bullet}\left(-1.83 \mathrm{~V}\right.$ vs. $\left.\mathrm{Fc}^{*}\right),{ }^{19}$ thus improving the injection of an electron into the LUMO.

According to this mechanistic hypothesis, probe 2 should indeed not experience any change in the ECL: (1) there is no small triply-charged cavity, and (2) due to acetate binding to the remote imidazolium units, the acetate is not brought next to the phenanthroline as a LUMO component.

Testing a sample containing all three anions in $\mathrm{MeCN}\left(\left[\mathrm{F}^{-}\right]=\right.$ $\left.\left[\mathrm{H}_{2} \mathrm{PO}_{4}^{-}\right]=10 \mu \mathrm{M},\left[\mathrm{AcO}^{-}\right]=0.20 \mathrm{mM}\right)$, the following analysis was obtained using probe $1(10 \mu \mathrm{M})$ and its single-anion calibration curves. The concentration of $\mathrm{F}^{-}$was determined to be $10.9 \mu \mathrm{M}$ from the absorbance at $457 \mathrm{~nm}$ in the UV-Vis channel, the concentration of $\mathrm{H}_{2} \mathrm{PO}_{4}{ }^{-}$as $8.2 \mu \mathrm{M}$ by using the PL intensity at $607 \mathrm{~nm}$ after adding $\mathrm{Me}_{3} \mathrm{SiCl}(10 \mu \mathrm{M})$ and the concentration of $\mathrm{AcO}^{-}$as $0.18 \mathrm{mM}$ by the ECL intensity at $602 \mathrm{~nm}$.

In summary, the first lab-on-a-molecule for quantifying three anions was established based on the iridium-imidazolium conjugate 1, despite the common notion that interactions between anions and imidazolium are rather unspecific. The interferences visible in competitive single-channel assays (Fig. S6, S15 and S23, ESI $\dagger$ ) of 1 are eradicated using the supremacy of triple-channel detection. However, changes in the $\mathrm{pH}$ are not tolerated (ESI $\dagger$ ).

\section{Notes and references}

$\ddagger \mathrm{Fc}^{*}$ is decamethylferrocene, $E_{\mathrm{Fc}^{*}}=-0.13 \mathrm{~V} v s$. SCE.

1 (a) G. T. Spence and P. D. Beer, Acc. Chem. Res., 2013, 46, 571; (b) L. E. Santos-Figueroa, M. E. Moragues, E. Climent, A. Agostini, R. Martínez-Máñez and F. Sancenón, Chem. Soc. Rev., 2013, 42, 3489.

2 (a) D. C. Magri, G. J. Brown, G. D. McClean and A. P. de Silva, J. Am. Chem. Soc., 2006, 128, 4950; (b) A. P. de Silva and S. Uchiyama, 
Nat. Nanotechnol., 2007, 2, 399; (c) A. P. de Silva, Chem. - Asian. J., 2011, 6, 750.

3 D. Margulies, C. E. Felder, G. Melman and A. Shanzer, J. Am. Chem. Soc., 2007, 129, 347.

4 M. Dong, Y. Peng, Y.-M. Dong, N. Tang and Y.-W. Wang, Org. Lett., $2012,14,130$.

5 M. Schmittel and H.-W. Lin, Angew. Chem., Int. Ed., 2007, 46, 893. 6 A. P. de Silva, Nature, 2007, $\mathbf{4 4 5}, 718$.

7 (a) A. T. Wright and E. V. Anslyn, Chem. Soc. Rev., 2006, 35, 14; (b) D. R. Walt, Chem. Soc. Rev., 2010, 39, 38.

8 O. A. Bozdemir, R. Guliyev, O. Buyukcakir, S. Selcuk, S. Kolemen, G. Gulseren, T. Nalbantoglu, H. Boyaci and E. U. Akkaya, J. Am. Chem. Soc., 2010, 132, 8029.

9 B. Rout, L. Unger, G. Armony, M. A. Iron and D. Margulies, Angew. Chem., Int. Ed., 2012, 51, 12477.

10 (a) N. Kaur and S. Kumar, Chem. Commun., 2007, 3069; (b) N. Singh, R. C. Mulrooney, N. Kaur and J. F. Callan, Chem. Commun., 2008, 4900; (c) N. Kaur and S. Kumar, Tetrahedron Lett., 2008, 49, 5067; (d) N. Singh, N. Kaur, C. N. Choitir and J. F. Callan, Tetrahedron Lett., 2009, 50, 4201; (e) E. Berni, I. Gosse, D. Badocco, P. Pastore, N. Sojic and S. Pinet, Chem. - Eur. J., 2009, 15, 5145; $(f)$ D. Y. Lee, N. Singh and D. O. Jang, Tetrahedron Lett., 2010, 51, 1103; $(g)$ D. Y. Lee, N. Singh and D. O. Jang, Tetrahedron Lett., 2011, 52, 3886; (h) M. Schmittel and S. Qinghai, Chem. Commun., 2012, 48, 2707;

(i) Q. Shu, L. Birlenbach and M. Schmittel, Inorg. Chem., 2012,
51, 13123; (j) V. K. Bhardwaj, P. Saluja, G. Hundal, M. S. Hundal, N. Singh and D. O. Jang, Tetrahedron, 2013, 69, 1606.

11 (a) A. Juris, V. Balzani, F. Barigelletti, S. Campagna, P. Belser and A. von Zelewsky, Coord. Chem. Rev., 1988, 84, 85; (b) L. Flamigni, A. Barbieri, C. Sabatini, B. Ventura and F. Barigelletti, Top. Curr. Chem., 2007, 281, 143; (c) Y. You and W. Nam, Chem. Soc. Rev., 2012, 41, 7061.

12 J. Li, P. I. Djurovich, B. D. Alleyne, M. Yousufuddin, N. N. Ho, J. C. Thomas, J. C. Peters, R. Bau and M. E. Thompson, Inorg. Chem., 2005, 44, 1713.

13 (a) K. Chen and M. Schmittel, Analyst, 2013, 138, 6742; (b) K. Chen, J. W. Bats and M. Schmittel, Inorg. Chem., 2013, 52, 12863.

14 (a) Z. Xu, S. K. Kim and J. Yoon, Chem. Soc. Rev., 2010, 39, 1457; (b) N. Ahmed, B. Shirinfar, I. S. Youn, A. Bist, V. Suresh and K. S. Kim, Chem. Commun., 2012, 48, 2662; (c) D. Zhang, X. Jiang, H. Yang, Z. Su, E. Gao, A. Martinez and G. Gao, Chem. Commun., $2013,49,6149$.

15 H. Lin, M. E. Cinar and M. Schmittel, Dalton Trans., 2010, 39, 5130. 16 C. Dragonetti, L. Falciola, P. Mussini, S. Righetto, D. Roberto, R. Ugo, A. Valore, F. De Angelis, S. Fantacci, A. Sgamellotti, M. Ramon and M. Muccini, Inorg. Chem., 2007, 46, 8533.

17 Y. You and S. Y. Park, J. Am. Chem. Soc., 2005, 127, 12438.

18 Q.-S. Lu, L. Dong, J. Zhang, J. Li, L. Jiang, Y. Huang, S. Qin, C.-W. Hu and X.-Q. Yu, Org. Lett., 2009, 11, 669.

19 R. Y. Lai and A. J. Bard, J. Phys. Chem. A, 2003, 107, 3335. 